\title{
THE PATTERN OF DEVELOPMENT OF ISLAMIC EDUCATION (HISTORICAL STUDIES)
}

\author{
Moch Tolchah \\ e-mail: mochtolchah@gmail.com
}

\begin{abstract}
Abstrak: This reseach aimed to determine the pattern of development of islamic education. The method used in this reseach was qualitative. The results of this research, the period before Indonesia's independence there are different patterns of development of Islamic education, namely: (1) isolatif-traditional, in the sense of not willing to accept anything that smells Western (colonial) and the inhibition effect of modern thinking in Islam to enter into it, as was evident at the boarding school education featuring only traditional religious sciences of Islam and common knowledge is not at all given. The essence of Islamic education is an effort to conserve and maintain the treasures of earlier scholars thought as expressed in their books. The main purpose of education is to prepare prospective chaplain or clergy only controlled religious issues alone. (2)Synthesis, which brings the livery (Islamic boarding school) and the new style (colonial or Western education model) tangible schools or Madrasah. In reality, patterns of thought this synthesis contain some variation of the pattern of development of Islamic education. (3) Various models and patterns of development of Islamic education are essentially intends to develop teachings and fundamental values contained in the Quran and al-Sunnah. It's just that they have a different perspective to understand and describe the nature of Islamic education and science. This implies also to formulas educational objectives, content / Islamic education materials as well as aspects of the methodology.
\end{abstract}

Key Words: Islamic Education, Madrasah, Boarding School, Modern School

\section{A. Introduction}

Activities of Islamic education in Indonesia basically has lasted and grown since before Indonesia's independence until now. It can be seen from the growth of the phenomenon of Islamic educational programs and practices implemented in the archipelago. Buchori ${ }^{1}$ mapped the internal structure of the Indonesian Islamic education, if judging from the aspect of education programs and practices into four (4) types, namely: (1) educational boarding school; (2) Madrasah education; (3) general education based on Islam; and (4) Islamic studies organized in institutions of public education as a subject or subjects only. The writer adds

${ }^{1}$ Mochtar Buchori, Pendidikan Islam Indonesia: Problema Masa Kini dan Perspektif Masa Depan, Dalam Muntaha Azhari\&Abd. Mun'imSaleh (Ed.), Islam Indonesia Menatap Masa Depan (Jakarta: P3M, 1989), 184 with: (5) Islamic education in the family or in places of worship, and / or in the forums Islamic studies, Islamic study groups, and other institutions that are now being promoted by the public. The fifth type is usually called the Islamic education outside of school.

These five types of Islamic education are essentially boils down to a full understanding, that is Islamic education is education that is established and organized on the basis of passion, motivation, and passion to manifest or embody Islamic values, good values and the values of divinity humanitarian values, through educational activities as covered in the five programs and practices of Islamic education that is mentioned above.

In history, the development of the five types of Islamic education that was already a serious discourse among the leaders of Islamic education since 
before Indonesia's independence. This paper intends to explore a variety of patterns of thought growing Islamic education development in the period before Indonesia's independence, especially since the early 20th century until about the time of independence (1945).

$\mathrm{Azra}^{2}$ mapped the patterns of study Islamic education in Indonesia as contained in the literature available over the years, into three (3) categories, namely: (1) the study of the sociohistorical Islamic education; (2) study the thinking and theory of Islamic education; and (3) a methodological study of Islamic education. Judging from the three patterns, the study is more focused on the former, namely sociohistorical study of Islamic education.

According to the authors assumption, that the development of Islamic education in Indonesia, especially in the period before Indonesia's independence (1900 - ahead of 1945), it seems more aimed at efforts to confront the colonial education. In that period thought to arise various problems and issues prominent Islamic education, which is a discourse in the development of Islamic education, especially among thinkers, developers and managers of Islamic education in Indonesia.

This study needs to be done, especially in anticipation of the development of contemporary Islamic education to be trapped into a development pattern that is regressive and conservative, given the atmosphere of the times and the socio-cultural context different. The development of Islamic education is run in place and / or

${ }^{2}$ Azyumardi Azra, Pendidikan Islam Tradisidan Modernisasi Menuju MileniumBaru (Jakarta: Logos Wacanallmu, 1999), 85-93 recede into the back of expected to be hampered by many problems in the era of science and technology development and globalization.

\section{B. Results \\ 1. Education Development Format before Independent of Indonesia}

In the early 20th century $\mathrm{AD}$, education in Indonesia was split into two categories, namely: (1) education provided by schools is secular West that does not recognize religious teachings; and (2) the education given by the boarding school who only knows the religion only. ${ }^{3}$ Or according to the terms Wirjosukarto (1985) in that period there were two patterns of education, the old pattern centered in boarding school and a new style of education (schools) were established by the Dutch government. ${ }^{4}$

Steenbrink research result (1986) suggests that colonial education is very different from traditional Indonesian Islamic education, not only in terms of methods, but more specifically in terms of content and purpose. Education run by the colonial government, especially centered on worldly knowledge and skills that is public education. While Islamic institutions with more emphasis on knowledge and skills useful for the appreciation of religion. ${ }^{5}$

Wirjosukarto (1985) more detailing the characteristics of each style of education. The characteristics of the old patterns are: (1) prepare prospective chaplain or clergy only control knowledge not at all given; (2) Less

\footnotetext{
${ }^{3}$ A. Mukti Ali, Memahami Beberapa Aspek Ajaran Islam (Bandung: Mizan, 1991), 193

4 Amir Hamzah Wirjosukarto, Pembaharuan Pendidikan dan Pengajaran Islam (Jember: Muria Offset, 1985, Cet. IV), 47

5 Karel A. Steenbrink, Pesantren Madrasah Sekolah Pendidikan Islam dalam Kurun Modern (Jakarta: LP3ES, 1986), 24
} 
given the knowledge to face the struggles of daily life and not given general knowledge; (3) the attitude of isolation caused by the non-cooperative attitude of the total of the boarding party to anything that smells Western and Islamic revival not flow freely to enter because hindered by the Dutch government. While the characteristics of newness is: (1) only highlight the intellect and at the same time to give birth class intellect; (2) generally negative attitude towards Islam;(3) The Natural mind Alienated from the life of the nation. ${ }^{6}$ Chasm that separates between the two classes is increasingly evident and increasingly widespread, both in social activities as well as intellectual, in the ways of hanging out, dress, speak, and think and so on. Western intelligentsia called intellect, whereas the intelligentsia islamic boarding school called scholar (in the narrow sense). ${ }^{7}$

With the fragmentation of education into two very different complexions, of course, will not have benefit the development of the Indonesian people to come, in fact it will disserve the Muslim community itself. Therefore, these differences should be eliminated or at least reduced so as not sharp, by the way: (1) establish educational places where religious science and general science are taught together; (2) provide religious lessons in public schools are secular.

The ideal purpose is the first attempt, so if it is successfully implemented, it will be born clerics (intelligentsia) which besides versed in religious sciences also understand the

\footnotetext{
${ }^{6}$ Amir Hamzah Wirjosukarto, Pembaharuan Pendidikan, 47-48

${ }^{7}$ A. Mukti Ali, Memahami Beberapa Aspek Ajaran Islam, 193
}

general sciences. From this comes the idea of clerical-intelligentsia. Meanwhile, a second attempt to fill the void intends Western intelligentsia religion, at least a negative attitude towards religion can be removed, or it would be better if can be accomplished much more than that, so they concern the deepening of religion by his own efforts. This effort will be born of intellectscholars, that a man who knows the general knowledge but also understands the problems of religion. Those efforts, among others, performed by Sheikh Abdullah H. Ahmad (1878-1933 AD) and K.H. Ahmad Dahlan(18681923AD).

From the description above it can be affirmed that in addition to the two shades of schools mentioned above, there is also a third educational pattern which is a synthesis of old and new style patterns. He tried to enter general education at religious schools and religious education to enter the public schools, which are embryonic an effort for the preparation of candidates for clerical-intellectual and / or intellectscholar.

\section{Models of Islamic Education Development}

The foregoing description underscored the three models of educational development, namely: education model boarding school, colonial education, and synthesis models. The following study attempts to understand further the education of the first pattern (Islamic boarding school) and the third mode of education (synthesis), while the second mode of education which is not a lot of concern in this study, because he did not develop Islamic education. 
Wirjosukarto results of the study showed that the main purpose of education is to prepare candidates boarding school graduates who only mastered religious issues alone. Lesson plan (curriculum) is determined by Kiyai by pointing out what books should be studied. The use of the book begins on the type of book that is low in the disciplines of Islamic science to a high level. The increase in grade or level characterized by the alternation of the book that can be studied after the books of previously completed studies. The size of wisdom not only the number of books students studied but measured by the teaching practice as a tutor, can understand the books are hard and teach other students. ${ }^{8}$

The views are based on the idea that human nature is as' abd Allah is always held vertical relationship with God in order to attain piety and happiness in this world and hereafter. To realize that these relationships necessary education and instruction in Islam. At the beginning of the level, the content of Islamic education include: (1) learn to read Al Qur'an and have no fell need to understand the content; (2) learning and practice of prayer; and (3) lessons divinity (theological) or ketauhidan that the outline is centered on the nature of twenty. For those who want to make deeper their religion given lessons Arabic, fiqh and fiqh are generally written in Arabic.

Fiqh is the tahaharah, prayer, alms, fasting and pilgrimage. At the higher level studied are also learn about

${ }^{8}$ Amir Hamzah Wirjosukarto, Pembaharuan Pendidikan, 27-28 the rules of marriage, talaq, also reconciliation faraidl(inheritance law). ${ }^{9}$

According to Mahmud Yunus (1979), that the content of Islamic education in boarding schools, especially at a time of changes (1900-1908) include: (1) the recitation of the $\mathrm{Al}$ Quran; (2) study the book consisting of several levels, namely: (a) assesses nahwu, sharf and fiqh using Ajrumiyah book, honor Bina, FathQarib and so forth; (B) assesses monotheism, nahwu, sharf and fiqh using books Sanusi, Shaikh Khalid (Azhari, 'Ashmawi), Kailani, FathMu'in and so forth; and (c) assesses monotheism, nahwu, sharf, fiqh, tafsir and others by using books Kifayatul 'Awam (Umm-Barahin), Ibn' Aqil, Mahalli, Jalalain / Baidlawi and so on. ${ }^{10}$

The Contents of Islamic education if viewed from in terms of the classification of knowledge as expressed in General Recommendation Conference on Muslim Education First (1977) in Mecca, the knowledge developed by the boarding school when it is more emphasis on Given perennial knowledge, the eternal knowledge are revealed, which based on divine revelation contained in the Quran and al-Sunnah and all the knowledge that comes from both of them with an emphasis on the Arabic language as a key to understanding both. While the "Acquired knowledge" (knowledge acquired) is not given at all at the school. ${ }^{11}$

\footnotetext{
${ }^{9}$ Deliar Noer, Gerakan Modern Islam di Indonesia 1900-1942 (Jakarta: LP3ES, 1985, Cet. III), 14-16.

${ }^{10}$ Mahmud Yunus,, Sejarah Pendidikan Islam di Indonesia (Jakarta: Mutiara, 1979), 54-55.

11 Syed Ali Ashraf, New Horizons In Muslim Education (London: The Islamic Academy, Cambridge and Hodder and Stoughton, 1984), 26.
} 
Therefore the function of Islamic education is to preserve and defend the values of the divine and the human, as contained in the scholar's books in the earlier. This function is inherent in each component of the activity of Islamic education. The essence of Islam is to realize educational goals mastery of knowledge of Islam as set forth and contained in the books of earlier scholars as well as products embedded deep religious feeling and practice it in our daily lives. The essence educator is one who is able to understand those religious books were tough and able to teach it to others. The essence of the learner is someone who is learning to understand religion (as stated in the books of History) and develop deep religious feelings. The curriculum is a lesson plan as stated in the books of previous religious scholar's product. Evaluation is an assessment of the ability of students to be the books studied to further increase in learning new book set by Kiyai.

While the educational model synthesis coincided with the emergence of Madrasah which is have the high level that emerged since 1909. The results of the research Yunus Mahmud showed that, Islamic education initially which is have the high level and put benches, desks and blackboard,is Adabiyah School / Madrasah Adabiyah (Adabiyah School) in Padang. This is the Madrasah (religious school) is the first in Minangkabau, even throughout Indonesia, which was founded by Sheikh Ahmad Abdullah in 1909. This Adabiyah life as Madrasah (religious school) until 1914, then changed into HIS Adabiyah in 1915, which is the first HIS in Minangkabau that included religious lessons in their lesson plan.
According Steenbrink, Adabiyah School was first established in Padang Panjang (1907), but has not reached the age of one year the school was closed and moved to Padang. The causes of failure among other things because it is less profitable to trade fabric (where Abdullah Ahmad active work) and the desire to publish a newspaper, while the facilities and good relations are in Padang. In addition, owing to the resistance in Padang Panjang to the establishment of the school, so that at its inception almost none of his students.

This type of education cannot be separated from the influence of the ideas of the reformers Middle East such as Muhammad Abduh and their intensive contacts with colleagues in Singapore, Sheikh Tahir Jalaluddin, who had planned the establishment of the modern Madrasah in Singapore as published in al-Imam magazine Singapore edition. In addition, a strong desire Abdullah Ahmad to establishAdabiyah Madrasah also grow because look orderly and well gubernemen school in Padang. ${ }^{12}$

Steenbrink describes the early days of the 20th century as a period of revival, renewal and even enlightened Islamic education in Indonesia. Among the motivator factor, Steenbrink said, is because some people in Indonesia who studied Islam in Malaysia, India or Egypt in addition to Mecca have known forms of Western education. In addition, groups of Arab communities in big cities in Indonesia at that time often bring in teachers from Tunisia or Syria. The teachers are mostly already acquainted with Western education system, mainly influenced by the French, who among Arab Muslims they are very much

\footnotetext{
${ }^{12}$ Maksum, Madrasah Sejarah dan Perkembangannya (Jakarta: Logos Wacana Ilmu, 1999), 100.
} 
appreciated and their passing was also the Western education system into Indonesia. On the other hand quite a lot of people and Islamic organizations are not satisfied with the traditional methods of studying the Koran and religious studies, then individuals and Islamic organizations at the beginning of the 20th century trying to improve Islamic education, both in terms of methods and content. They also seek the possibility of providing general education for Muslims. ${ }^{13}$

As a school that is actually a form of adaptation or adjustment of the education system Surau to the Western system, the attention to religious education in Adabiyah schools is very small. General education is more emphasized than religious education, because it turns very salable in Padang. It distinguishes between HIS organized by the Netherlands with HIS held by Abdullah Ahmad located in religious studies and teaches the Qur'an as a compulsory subject. ${ }^{14}$

To improve the quality of public education, Abdullah Ahmad inserts four teachers of the Dutch nation, in addition to the two Indonesian men who also have a diploma to teach at his level. In 1916 Adabiyah School is recognized by the government as his first established by Islamic organizations and subsidized by the colonial government in the form of funds and teachers. ${ }^{15}$

According to Stoddard (1966) that the educational institutions HIS Adabiyah is the starting point (new chapter) in the educational reforms that

\footnotetext{
${ }^{13}$ Karel A. Steenbrink, Pesantren Madrasah Sekolah, 26-28

${ }^{14}$ Abuddin Nata, Pemikiran Para Tokoh Pendidikan Islam (Jakarta: RajaGrafindo Persada, 2000), 162.

${ }^{15}$ Karel A. Steenbrink, Pesantren Madrasah Sekolah, 39-40
}

affect the establishment of educational institutions of modern Islam that is not confined to the primary school level, but also the level of junior and senior secondary to high levels with various name. ${ }^{16}$

It's just that Adabiyah school education model is still considered too profane in Minangkabau, because very little of religious subjects and style rather westernized. Therefore Schools Adabiyah judged negatively by many people (especially among the traditional scholars), and its orientation to the West that are causing the main purpose of this school as a pillar of the modernist movement was considered a failure. K.H. Zarkasyi, founder of Pondok Gontor Roxburgh, who had studied at the School Adabiyah, stated that "Abdullah Ahmad was not a Modernisator but a Hollandisator". ${ }^{17}$

Another figure in educational reform Islam in Minangkabau is Zainuddin Lebay el-Yunusiy (18901924), who established the Madrasah Diniyah (Diniyah School) in 1915 in Padang Panjang, with the classical system and the arrangement of lessons consisting of religious sciences and Arabic, coupled with morals and general sciences, particularly history and earth science. ${ }^{18}$

In general, this madrasah is more emphasis on the mastery of Arabic, so that the higher grade texts for general knowledge also using Arabic language books, and thereby are more extra subjects of Arabic language on earth science or history. According to the

\footnotetext{
${ }^{16}$ Stoddard, Lothrop, The New World of Islam, terj. Mulyadi Joyomartono (Jakarta: t.p., 1966), 3044

${ }^{17}$ Karel A. Steenbrink, Pesantren Madrasah Sekolah, 42

${ }^{18}$ Mahmud Yunus,, Sejarah Pendidikan Islam di Indonesia (Jakarta: Mutiara, 1979), 68
} 
assessment Maksum, Diniyah Madrasah education is a form of Islam that is consistent with the pattern offered by the reform movement in the Middle East, and in general the material and the style is more Islamic education, so that it is more acceptable in a wider circle. Unlike the case with Adabiyah Madrasah (Abdullah Ahmad), which is a Dutch school with educational the materials of religion.

The figure has a pattern similar to the activities undertaken by Abdullah Ahmad in Padang is K.H. Ahmad Dahlan (1868-1923 AD), which on 18 November 1912 establishing the organization Muhammadiyah along with his friends in the city of Yogyakarta. It is the same which is said to be especially it can be seen from three things: (1) activities of Tabligh, that religious instruction for groups of adults in the courses regularly; (2) establishing private schools according to the educational model gubernemen with plus several hours of religious instruction per week; (3) to establish a cadre of organizations and religious teachers, founded Pondok Muhammadiyah as Normal Islam in Padang in 1931. ${ }^{19}$

The results Wirjosukarto studies ${ }^{20}$ showed that Muhammadiyah islamic boarding school which stands around 1920 has been using modern educational delivery system that is different from the old boarding school. The difference can be seen from six aspects, namely: (1) ways of teaching and learning, long used for boarding and weton sorogan system which results are considered less efficient, while at the cottage Muhammadiyah used classical system

\footnotetext{
${ }^{19}$ Karel A. Steenbrink, Pesantren Madrasah Sekolah, 55-56

${ }^{20}$ Amir Hamzah Wirjosukarto, Pembaharuan Pendidikan, 99-108
}

with Western ways which may be more efficient; (2) material, the pesantren longer just a religious issue alone and the books of works of renewal is not used, sedangan in cottage Muhammadiyah teaching materials remain religious, but also taught general science, religious books are widely used both works of scholars old and modern scholars; (3) the lesson plans, the old boarding school no lesson plans organized and integral, whereas in Muhammadiyah cottage is set up with a lesson plan so that efficiency learning is assured; (4) education outside of time-time study, at the old boarding too free time learning and less guided, while at the cottage Muhammadiyah held in the dorm guided on a regular basis; (5) caretakers (teachers), at the old boarding caregivers longer covered by the nature of mind, while at the cottage Muhammadiyah consists of the scholars who embrace the modern mind; (6) the relationship between teachers and students, at the old boarding more authoritarian and less democratic, while at the cottage Muhammadiyah cultivated atmosphere of the teacher-student relationship is more intimate, free and democratic.

In the socio-economic field Muhammadiyah is far more active than the Islamic reformist movement in Padang. In addition, judging from its influence on the reform of Islamic education in Indonesia, activities Abdullah Ahmad does not have much effect because he was considered too progressive, and in West Sumatra came a strong movement of Padang Panjang which focuses on the activities of religious education, the Madrasah Diniyah and Sumatra Thawalib. Madrasah Diniyah Padang Panjang is under the leadership of Zainuddin Lebai el-Yunusi. While the first to wear Surau 
class system is Thawalib Sumatra Padang Panjang under the leadership of Sheikh Abdul Karim Amrullah. ${ }^{21}$

Unlike the case with Muhammadiyah which succeeded in establishing and developing the educational reform by imitating gubernemen education model, although it does not mean at all apart from the controversial reactions. ${ }^{22}$ Muhammadiyah's success is due to the fact that he faces a social environment that is limited to employees, teachers and traders in the city. The group is concerned with the education model of the West, thus providing western education model coupled with the religious education of Muhammadiyah get good results.

Meanwhile educational aims of K.H. Ahmad Dahlan or educational aims Muhammadiyah itself, according to the conclusions Wirjosukarto (1985) after conducting interviews with people who knew of the close of ideas and efforts in the field of education and teaching, is the human form of Muslims who: (1) considerate, pious in religion; (2) broad view, pious in the world sciences (general knowledge); and (3) is willing to fight for the progress of society. ${ }^{23}$ From the study results philosophically, Wirjosukarto also formulates educational outcomes desired by KH. Ahmad Dahlan, namely: (1) Muslim high moral comes from the teachings of the Qur'an and Sunnah with the understanding broadly; (2) Muslims who have rounded individuality, in the sense of balance between the spiritual and physical

${ }^{21}$ Mahmud Yunus, Sejarah Pendidikan Islam di Indonesia (Jakarta: Mutiara, 1979), 63-73

${ }^{22}$ Karel A. Steenbrink, Pesantren Madrasah Sekolah, 56-57

${ }^{23}$ Amir Hamzah Wirjosukarto, Pembaharuan Pendidikan, 74 development, between faith and intellect, between feelings and thoughts, between science ukhrawi and worldly; (3) Muslims who have positive social attitudes in a sense always ready to work progress of their society.

Those three things have to come together, is a harmonious amalgamation, gave birth to one individual Muslim who deserve to be called a servant of God or a divine servant. To achieve these goals, he developed an Islamic education by using two systems, namely: (1) school that follows the pattern gubernemen is coupled with religious subjects; and (2) Madrasah more teaches religious sciences. $^{24}$ In between school and Madrasah were quite meritorious and established in colonial times was Kweekschool Muhammadiyah, Muhammadiyah Muallimin, Muallimat Muhammadiyah, Muhammadiyah HIS, MULO Muhammadiyah, Yogyakarta Muhammadiyah, Muhammadiyah MI, MTs / Wustha Muhammadiyah. With varying proportions, in all schools and Madrasah was given general subjects and religious subjects in a balanced manner.

The core of the educational materials or curriculum includes three aspects, namely: (1) the moral education, morals, that in an effort to instill a good human character based on the Quran and al-Sunnah; (2) education of individuals, which is an effort to raise awareness of individual intact berkeseimbangan between mental and physical development, between faith and intellect, the feeling with the mind and the world to the Hereafter; (3) the education community, ie an attempt to cultivate the

\footnotetext{
${ }^{24}$ Maksum, Madrasah Sejarah dan Perkembangannya (Jakarta: Logos Wacana Ilmu, 1999), 108
} 
willingness and desire of community life. $^{25}$

In addition, there are other figures that play a role in education reform Islam in Java, namely $\mathrm{KH}$. Hasyim Ashari, who had introduced the pattern of Madrasah education in boarding schools Tebu Ireng Jombang in East Java. Pesantren was established in 1899 which is more focused on teaching religious sciences and Arabic with sorogan and bandongan system. In 1919 this school had experienced a renewal mainly from teaching system which was originally performed by the system sorogan and bandongan improved by using a classical system, which is famous madrasah system. Thus, the school is a sub-system of the education system pesantren Tebu Ireng.

With a very central position in the network of boarding schools in Java, then renewal happens at the school quickly spread to other boarding schools, like in Kediri, Demak, Kudus, Cirebon and Banten. Even more so after the formation of associations Nahdlatul Scholars in 1926, what do KH. Hasyim Ashari as a model for the assembly effort in the field of education.

Having handled by KH. Hasyim Ashari for about 6 years, the management of Madrasah was then handed over to $\mathrm{KH}$. Ilyas. Under his leadership, the school originally pure nature diniyah later developed into a madrassa also taught general sciences, such as reading and writing Latin letters, Indonesia language, geography, history and arithmetic Indonesia.

\section{Conclusion}

${ }^{25}$ MT. Arifin, Gagasan Pembaharuan Muhammadiyah (Jakarta: Pustaka Jaya, 1987), 25
From the various descriptions of above can be affirmed that in the period before Indonesia's independence there are different patterns of development of Islamic education, namely:

1. isolatif-traditional, in the sense of not willing to accept anything that smells Western (colonial) and the inhibition effect of modern thinking in Islam to enter into it, as was evident at the boarding school education featuring only traditional religious sciences of Islam and common knowledge is not at all given. The essence of Islamic education is an effort to conserve and maintain the treasures of earlier scholars thought as expressed in their books. The main purpose of education is to prepare prospective chaplain or clergy only controlled religious issues alone.

2.Synthesis, which brings the livery (Islamic boarding school) and the new style (colonial or Western education model) tangible schools or Madrasah. In reality, patterns of thought this synthesis contain some variation of the pattern of development of Islamic education, namely: (1) the pattern of development of madrasa education follows the format of Western education, especially in the teaching system in the classical style, but the content of education still further highlight the religious sciences of Islam, as developed in Thawalib Sumatra and Madrasah Madrasah Tebu Ireng KH leadership. Hasyim Ashari; (2) the pattern of development of madrasa education that prioritizes subjects-religious subjects, but subjects-general subjects also given a limited basis, such as those developed by Madrasah Diniyah Zaenuddin Lebau el-Yunusi 
and Madrasah Salafi leader Tebu Ireng KH. Ilyas; (3) the pattern of development that combines Madrasah education is more balanced between the charges of religious and nonreligious, such as those developed by the cottage Muhammadiyah; and (4) a development pattern that follows the pattern of school education gubernemen added some religious subjects, as developed by the Madrasah Adabiyah (Adabiyah School) and Muhammadiyah school.

3. Various models and patterns of development of Islamic education are essentially intends to develop teachings and fundamental values contained in the Quran and alSunnah. It's just that they have a different perspective to understand and describe the nature of Islamic education and science. This implies also to formulas educational objectives, content / Islamic education materials as well as aspects of the methodology.

\section{References}

Arifin, MT. (1987). Gagasan Pembaharuan Muhammadiyah. Jakarta: Pustaka Jaya.

Ali, A. Mukti. (1991). Memahami Beberapa Aspek Ajaran Islam. Bandung: Mizan.

Ashraf, Syed Ali. (1984). New Horizons In Muslim Education. London: The Islamic Academy,
Cambridge and Hodder and Stoughton.

Azra, Azyumardi. (1999). Pendidikan Islam Tradisi dan Modernisasi Menuјu Milenium Baru, Jakarta: Logos Wacana Ilmu.

Buchori, Mochtar. (1989). Pendidikan Islam Indonesia: Problema Masa Kini dan Perspektif Masa Depan, Dalam Muntaha Azhari \& Abd. Mun'im Saleh (Ed.), Islam Indonesia Menatap Masa Depan, Jakarta: P3M.

Maksum. (1999). Madrasah Sejarah dan Perkembangannya. Jakarta: Logos Wacana Ilmu.

Nata, Abuddin. (2000). Pemikiran Para Tokoh Pendidikan Islam. Jakarta: RajaGrafindo Persada.

Noer, Deliar. (1985). Gerakan Modern Islam di Indonesia 1900-1942. Jakarta: LP3ES.

Steenbrink, Karel A. (1986). Pesantren Madrasah Sekolah Pendidikan Islam dalam Kurun Modern. Jakarta: LP3ES.

Stoddard, Lothrop.(1966), The New World of Islam, terj. Mulyadi Joyomartono. Jakarta: t.p.

Wirjosukarto, Amir Hamzah. (1985). Pembaharuan Pendidikan dan Pengajaran Islam. Jember: Muria Offset.

Yunus, Mahmud. (1979). Sejarah Pendidikan Islam di Indonesia. Jakarta: Mutiara. 